\title{
The actions and side effects of Anabolic Steroids in sport and social abuse
}

\author{
Alan James GEORGE \\ Liverpool John Moores University, London
}

\begin{abstract}
Anabolic steroids (AS) derived from testosterone have both anabolic (muscle and strength enhancing) and androgenic (primary and secondary sexual) effects. Efforts to limit the androgenic while enhancing the anabolic effects have not been successful. Alterations to the structure of testosterone, so as to improve the pharmacokinetics of AS, have resulted in drugs, which are orally active, have a longer plasma half life and may be administered as depot injections. Therapeutic doses of AS produce statistically significant effects on strength and athletic performance in well-controlled scientific and clinical trials. At low, therapeutic doses, diet and an intensive training regime are equally important in producing a statistically significant increase in strength. Higher doses $6-7000 \mathrm{mg}$ per week are regularly administered in sport and produce the greatest increases in muscle strength erythropoiesis and lean body mass. Patterns of steroid abuse can be complex, reflecting a desire to minimise side effects, and avoid detection. AS side effects are of many types. AS increase salt and water retention leading to an expansion of the blood volume, but effects of steroids on blood pressure are equivocal and most cardiovascular side effects appear to be reversible.
\end{abstract}

Abuse of AS causes an increase in blood triglyceride and cholesterol levels and this is associated with a decline in High Density Lipoproteins (HDLs) and an increase in the Low Density (LDL) type. Though these effects are reversible they are associated with an increased risk of both acute and chronic cardiovascular pathology. The most serious irreversible anabolic steroid side effects are associated with carcinomas - mainly of the liver, prostate and kidney. Hepatic carcinomas are strongly associated with abuse of the orally active 17alpha methyl substituted steroids, which also produce a reversible jaundice. In males, anabolic steroid abuse causes suppression of LH and FSH release leading to inhibition of testosterone production often accompanied by testicular atrophy, and azoospermia. High, chronic doses of the drugs may also cause moderate to severe feminising effects in the form of gynaecomastia. Male secondary sexual characteristics are a side effect of AS abuse in women. Increased insulin resistance and elevated fasting blood glucose levels are the commonest non-gonadal endocrine side effects of AS.

AS abuse leads to contradictory, complex, behavioural, and psychiatric changes. Increased frequency of mental illness, in anabolic steroid abusers including paranoid schizophrenia, mania and depression has been reported. Physical and psychological dependency occur amongst some anabolic steroid abusers and severe psychiatric disorders can appear upon withdrawal, leading in a few cases to criminality and even suicide. We need more studies on the long-term effects of AS. The implications of the past $\mathbf{5 0}$ years of AS abuse will be discussed in the review.

Key Words : anabolic steroids, androgenic anabolic steroids, testosterone, side-effects, sport, athletics, abuse, pathology, dependency, review, reversible, chronic

\section{Correspondance :}

Dr Alan James George - Reader in Clinical Pharmacology \& Director of Clinical Research Courses, School of Pharmacy and Chemistry, Liverpool John Moores University, Byrom Street, Liverpool, L3 3AF. U.K. 


\section{INTRODUCTION}

Goethe's legendary Zauberlehrling (Sorcerer's Apprentice) casts a spell to save time and effort in his Master's absence, only to find that the magic cannot be reversed. The promoters of anabolic steroid abuse are in a similar position.

Testosterone, from which anabolic steroids are derived, was first isolated in 1935 and synthetic derivatives became commercially available from 1945 . The last steroid-free Olympic Games is presumed to have been the controversial Berlin Olympics of 1936 [25].

Despite many rumours, there is no evidence that either testosterone or anabolic steroids were administered to the Nazi-Waffen $S$-S regiments during World War 2 [86].

The first documented appearance of anabolic steroid in a major sporting event was during the World Weight lifting Championships in Vienna in 1954 [86].

Since the 1950's there have been advances in the medicinal chemistry and pharmacology of the anabolic steroids [42, 78].

Anabolic steroids derived from testosterone have both anabolic (muscle and strength enhancing) and androgenic (primary and secondary sexual) effects and major efforts to limit the androgenic while enhancing the anabolic effects have not been successful. Alterations to the structure of testosterone, so as to improve the pharmacokinetics of anabolic steroids, have resulted in drugs, which are orally active, have a longer plasma half-life and may be administered as depot injections. Orally active anabolic steroids have a 17alpha-methyl substitution, which also increases their hepatic toxicity, while esterification with a long chain carboxylic acid allows the anabolic steroid to be used as a depot drug $[25,42,49]$.

Therapeutic doses of anabolic steroids are $2.5-10 \mathrm{mg}$ per day in the UK, and positive statistically significant effects on strength and athletic performance have been obtained using these doses in well-controlled scientific and clinical trials. At these low, "ethical" and therapeutic doses, diet and an intensive training regime are equally important in producing a statistically significant increase in strength [25]. Much higher doses 6-7000 mg per week are regularly administered in sport and recent research has shown that these supra-physiological treatments produce the greatest increases in muscle strength and size while also increasing erythropoiesis. This range of doses has also been shown to increase the lean body mass but evidence for an effect on aerobic power and endurance is equivocal and awaits further investigation [25].

Patterns of steroid abuse can be complex, reflecting a desire to minimise side effects, avoid detection or fulfil some ritualistic desire. The commonest regimes are: cycling in which the dosing occurs for 6-8 weeks followed by 6-8 weeks abstinence, pyramiding in which the drug is slowly built up and then reduced, and stacking in which several steroids, with different pharmacokinetic properties, are used together. There are female versions of these dosage programmes particularly for the cyclic type.

Anabolic steroid side effects are of many types. They may be short or long term, acute or chronic, reversible or irreversible, masculinising or feminising, systemic and /or behavioural [25]. Much more is known about the shortterm effects of anabolic steroids despite 50 years of their abuse. Anabolic steroids increase salt and water retention leading to an expansion of the blood volume, but studies on the effect of steroids on blood pressure are equivocal and most of these cardiovascular side effects appear to be reversible [62]. However, ventricular abnormalities including hypertrophy have been recognised in several recent studies of chronic steroid abusers though these have involved only small numbers of subjects. Abuse of anabolic steroids causes an increase in blood triglyceride and cholesterol levels and this is associated with a decline in High Density Lipoproteins (HDLs) and an increase in the Low Density (LDL) type [25, 49]. Though these effects are reversible they are associated with an increased risk of both acute and chronic cardiovascular pathology. Some of the pathological changes, which occur, may be easily detected in terms of an adverse blood lipid profile, but there are also subtle pathologies of the vascular endothelium which contribute to atherosclerosis [18].

Some of the most serious irreversible anabolic steroid side effects are associated with carcinomas - mainly of the liver, prostate and kidney. Hepatic carcinomas are strongly associated with abuse of the orally active 17alpha-amethyl substituted steroids, which are also prone to produce a reversible jaundice [25].

In males, anabolic steroid abuse is known to cause suppression of LH and FSH release leading to inhibition of endogenous testosterone production. This may be accompanied by testicular atrophy, and a reversible and sometimes irreversible azoospermia. High, chronic doses of the drugs may also cause moderate to severe feminising effects in the form of gynaecomastia. The mammary development is caused by the "aromatisation" of testosterone or other steroids (but not nandrolone) to oestradiol [49].

Male secondary sexual characteristics are a side effect of anabolic steroid abuse in women. They include growth of facial hair, deepening of the voice, pharyngeal enlargement, clitoral growth and skeletal changes. Though amenorrhoea is often found in female endurance athletes, steroid induced amenorrhoea may be permanent and when reversed may still be associated with infertility. 
Acne is the most common dermatological side effect of anabolic steroids and is particularly resistant to standard therapies. It is not always reversible.

Increased insulin resistance and elevated fasting blood glucose levels are the commonest non-gonadal endocrine side effects of anabolic steroids. They are usually reversible and the insulin resistance does not normally lead to Type II diabetes [25].

Abuse of anabolic steroids leads to complex behavioural, psychological and psychiatric changes upon which there is little agreement $[25,42]$. Many of the studies are contradictory and have been carried out in different and noncomparable groups of either athletes or non-athletes and often, different outcomes or psychological variables are being measured. Some studies indicate that aggression is increased in anabolic steroid abusers while others limit this to increases in sexual aggression arguing that an increased level of "controlled" aggression is necessary in the successful athlete [25]. Several investigators have found evidence of increased frequency of mental illness, as categorised by DSM IV and WHO criteria, in AS abusers, including paranoid schizophrenia, mania and depression [40, 55]. Equally disturbing are reports of physical and psychological dependency amongst some anabolic steroid abuser [11] and severe psychiatric disorders occurring upon withdrawal, leading in a few cases to criminality and even suicide [55].

We urgently need more studies on the long-term effects of anabolic steroids. One study carried out on steroid-abusing power lifters in Finland, suggests that anabolic steroid abuse reduces longevity: they were 4.6 times more likely to suffer a premature death than non-abusers [11].

In the following sections, evidence for the action and side effects of anabolic steroids will be assessed and discussed.

\section{TESTOSTERONE AND RELATED COMPOUNDS}

Testosterone and its synthetic and semi-synthetic derivatives and its immediate precursors are termed C- 19 steroid hormones, a classification based on the structure of the steroid androstane (Figure 1) [25]. When testosterone is synthesised in humans, its isomer epi-testosterone is also produced (Figure 1). After the discovery and isolation of testosterone in 1935, it was demonstrated that testosterone possessed both anabolic and androgenic properties [25, $42]$. It has proved almost impossible to separate these pharmacological activities $[25,42,86]$. Steroids, which mimic the action of testosterone, are known as anabolic androgenic steroids (AAS) or simply as anabolic steroids (AS).

\section{Testosterone Biosynthesis}

Testosterone $(\mathrm{T})$ originates like all steroid hormones, from cholesterol, but the immediate precursor is androstenedione, which is converted to testosterone by the enzyme 17- $\beta$ hydoxysteroid dehydrogenase (Figure 2) [25, 42, 75]. Recently, it has been discovered that the anabolic steroid nandrolone, which is 19-nortestosterone (Figure 1), can be formed in both males and females from 19-nor androstenedione [81]. The implications of this are discussed later and in also in detail by George [25] in a previous review.

\section{Testosterone metabolism}

Testosterone and its 19-nor derivative, nandrolone are converted to etiocholanolone and androsterone and their respective 19 -nor derivatives by the hepatic $3 \mathrm{alpha} / 3$ beta keto reductase enzyme system $[75,81]$. Testosterone and nandrolone may be converted by 5 alpha-reductase to their respective dihydro derivatives, but of these two only testosterone can be converted to oestradiol by aromatase [ 75 , $81,83]$.

\section{Actions of testosterone and anabolic steroids}

Testosterone produces its effects at the cellular level by :

1. diffusing across the cell membrane and binding to the cytosolic androgen receptor ;

2. conversion within the target cell to DHT (via the enzyme 5 alpha-reductase) ;

3. conversion in certain target cells to oestradiol via the aromatase enzyme system and binding then to the cytosolic oestradiol receptor.

All the above mechanisms involve the transfer of the receptor/hormone complex formed subsequently, to a hormone responsive element (HRE) in the genome.

Testosterone and possibly also AS may influence cellular activity by :

4. binding to and activating cell surface membrane receptors and consequently the activation of second messenger systems;

5. binding to modulatory (facilitatory or attenuator) sites associated with certain functional cell surface receptors such as the $\mathrm{GABA}_{A}$ receptor [29], particularly at its low affinity benzodiazepine binding site [84].

Testosterone and AS possess androgenic and anabolic effects. Modifications of the testosterone structure are of 3 major types: A, B and C. Esterification of the 17 beta-OH group with a long chain fatty acid produces Type $A$. The type B modification involves alkyl substitution at the 17 alpha position, while type $\mathrm{C}$ involves addition of chemical 


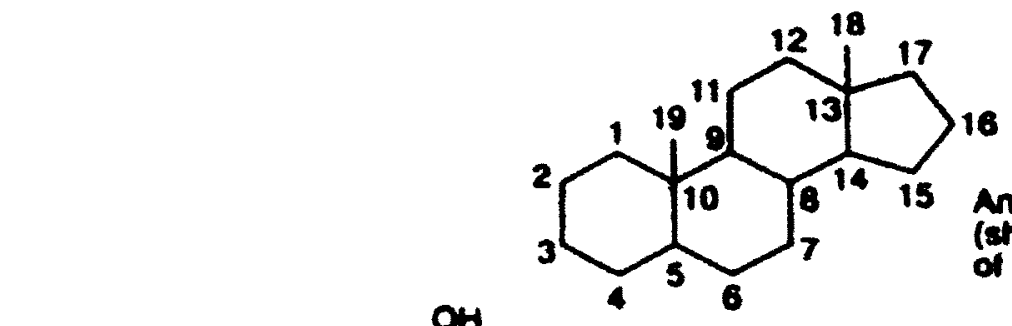<smiles>C[C@H]1CCC2C3CCC4=CC(=O)CCC4(C)C3CCC21C</smiles><smiles>CC12CCC(=O)C=C1CCC1C2CCC2(C)C(O)CCC12</smiles>

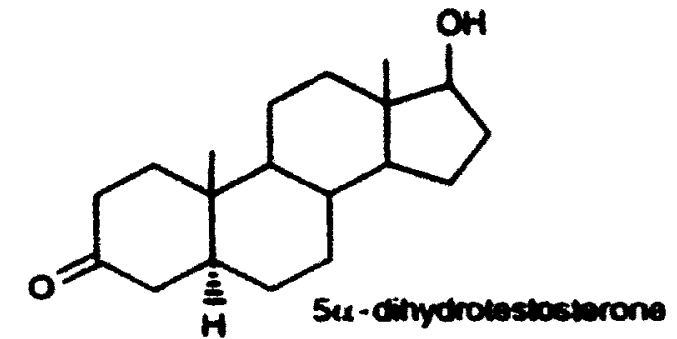<smiles>CC12CCC3C(CCC4=CC(=O)CCC43C)C1CCC2=O</smiles><smiles>CC12CCC3C(CC[C@H]4C[C@@H](O)CCC34C)C1CCC2=O</smiles><smiles>CC12CCC3C(CC[C@H]4CC(O)CCC34C)C1CCC2=O</smiles><smiles>CC12CCC(=O)C=C1CCC1C2CCC2(C)C1CCC2(C)O</smiles>

17u-methylleswoteron<smiles>CC12C=CC(=O)C=C1CCC1C2CCC2(C)C1CC[C@]2(C)O</smiles><smiles>CC12CCC3C(CC[C@H]4CC5NN=CC5CC34)C1CC[C@@]2(C)O</smiles>

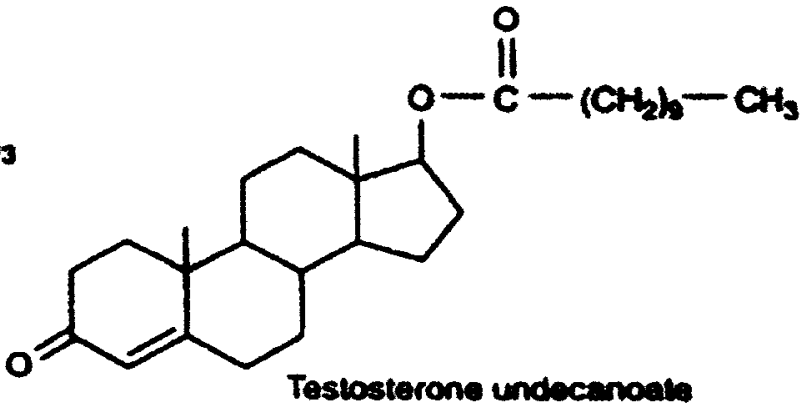

Figure 1 : The structure of testosterone and some of its synthetic derivatives - adapted from George [25]. 
<smiles>C[C@]12CC[C@H]3[C@@H](CC=C4CC(O)CC[C@]43C)[C@@H]1CCC2=O</smiles>

dehydroandrostenedione(DHEA)

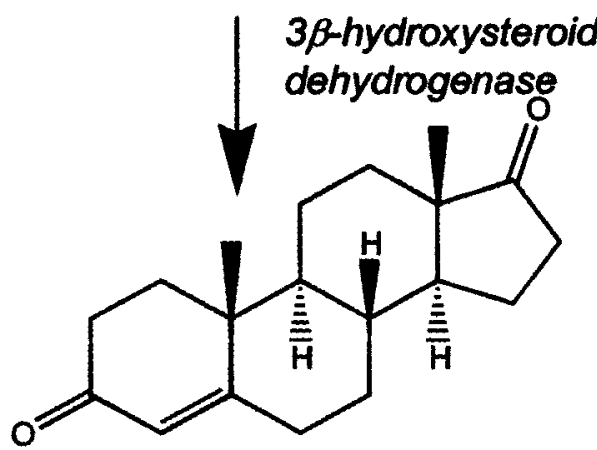

androstenedione

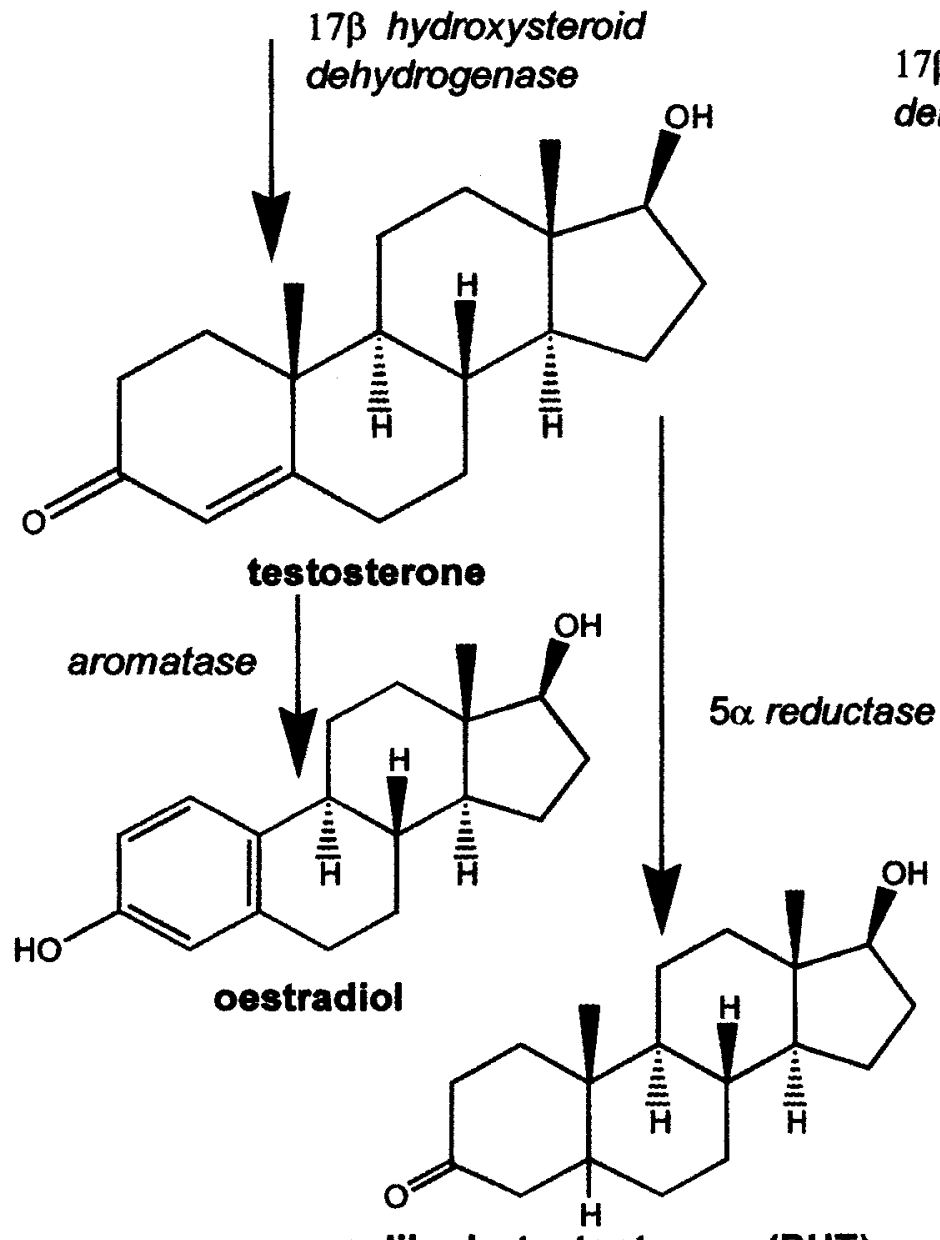

dihydrotestosterone (DHT)
HO<smiles>C[C@]12CC[C@@H]3[C@@H]4CCC(O)CC4=CC[C@H]3[C@@H]1CCC2=O</smiles>

19 nordehydroandrostenedione (19nor DHEA)

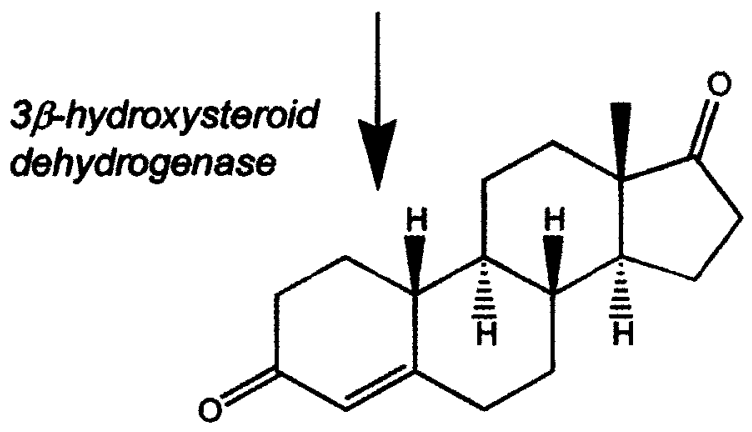

19 nor-androstenedione

$17 \beta$ hydroxysteroid dehydrogenase

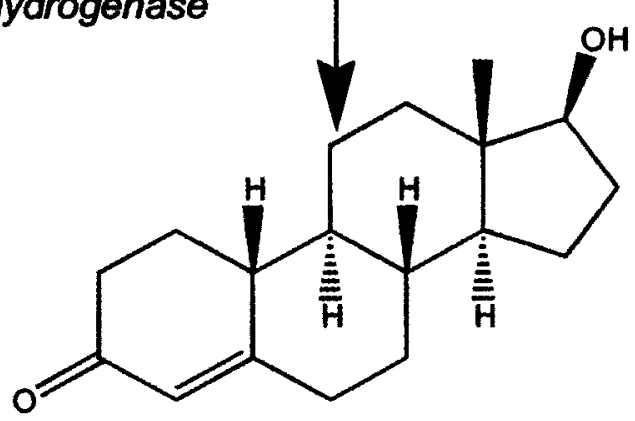

19 nor-testosterone

(Nandrolone)

$5 \alpha$ reductase

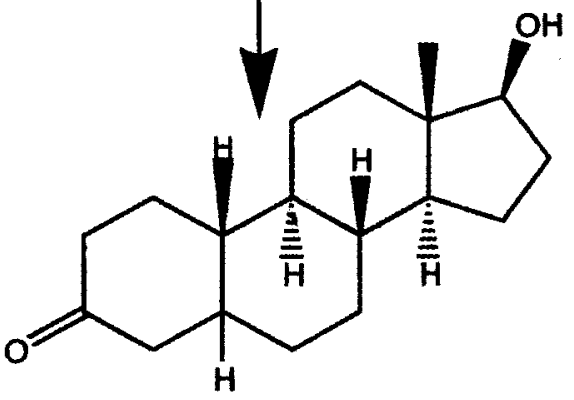

19 nor-dihydrotestosterone

Figure 2 : The biosynthesis of testosterone and its derivatives - adapted from George [25]. 
groups usually to positions 1-5. Type A substitutions produce injectable/depot preparations, Type B modifications confer oral activity, while type $\mathrm{C}$ changes reduce metabolism of the steroid. A full discussion of the impact of these modifications has been provided in a number of reviews $[24,25,42,49,78]$. Though the above changes also induce alterations in the ratio of anabolic / androgenic activity, some androgenic activity is still present in all AS [25, 42].

\section{Patterns of administration}

The pattern and route of administration of anabolic steroids varies from one group of abusers to another. It is determined as much by anecdotal evidence of efficacy as by deliberate attempts to avoid the detection of abuse by sporting and athletic authorities. Detailed reviews and analysis of AS administration regimes [25, 42] have yielded 3 major patterns which have been summarised as follows [25] :

a) Cycling : a period of drug administration followed by an equivalent period of abstinence ; then the drug is recommenced in a continuing pattern e.g. 6-8 weeks on/ 6-8 weeks off $/ 6-8$ weeks on etc. There may be intricate patterns of drug administration and short breaks or vice versa. Patterns of abstinence can be timed to coincide with competitions in order to avoid detection but the overall strategy is to reduce the incidence of side-effects $[25,43]$.

b) Pyramiding is a variation of cycling in which the dose is gradually built up in the cycle to a peak and then gradually reduced again towards the end of the cycle [25]. The regime is said to cause fewer behavioural side effects, such as lowered mood, caused by the withdrawal of the drug, though there is no published evidence of this.

c) Stacking involves the use of more than one anabolic steroid at a time. A stacking regime involves the simultaneous use of both an orally administered steroid and an injectable one. More «sophisticated» patterns involve intricate patterns of administration using many different steroids each with supposedly different pharmacological profiles. The aim of this technique is to avoid so-called plateauing ; that is the development of tolerance to a particular drug. These «super stacking" programmes are "designed" to maximise the occupation of cytosolic receptor sites. This is very dubious pharmacology since the number of intracellular testosterone/DHT steroid receptors is stable and all are probably saturated under normal physiological conditions, or at least when therapeutic doses of AS are used. The efficacy of this administration scheme has recently been challenged by others [43]. However, it is quite possible that the supra-physiological doses administered during stacking and the consequent supra-physiological AS plasma levels that result from this may lead to a displacement of glucocorticoids (GC) from the $\mathrm{GC}$ receptor leading to a reduc- tion in GC-induced protein catabolism [25, 62]. Such supra-physiological doses are at least 100 times those indicated for therapeutic use in the EU and US [63].

An alternative explanation is that the androgen receptor may be upregulated by supra-physiological AS doses [42], but this does not explain why supraphysiological doses of testosterone are able to reverse the muscle wasting present in individuals with androgen insensitivity syndromes [83].

In addition to the abuse of AS in complex patterns and cycles, other non-steroidal "anabolic" agents may be coadministered. Human chorionic gonadotrophin (hCG) is often abused by athletes to stimulate natural testosterone secretion from the testis [20] as this hormone has an LH like effect on the testicular Leydig cells [26]. Such abuse of hCG is frequently employed to counteract the suppression of LH induced by chronic AS administration [26]. Abuse of growth hormone $(\mathrm{GH})$ is suggested to reduce some of the lipid-elevating side effects of anabolic steroids - but there is no published evidence that this is true [25].

\section{Dosage}

In the UK, the standard maintenance dosage of testosterone in males, ranges from $40-120 \mathrm{mg} . \mathrm{d}^{-1}$. This is significantly less than the doses recorded in many clinical/ scientific studies of anabolic steroids [25, 42, 63, 78]. A doseresponse curve of the effect of anabolic steroid administration on lean body mass [21, 42] shows that such doses are at the base of the D-R curve while the maximum effect was achieved with doses in excess of $5000 \mathrm{mg}$ per week! Several recent studies have shown conclusively that these massive doses when used under controlled conditions produce statistically significant increases in muscle strength and lean body mass compared to both placebo and to "normal" clinical doses $[7,8]$.

\section{DO ANABOLIC STEROIDS WORK IN SPORT ?}

Until recently, the results of the effects of physiological doses of testosterone or anabolic steroids on muscle strength and athletic performance were often conflicting $[25,46]$. Major reviews of the published data since 1975 have highlighted crucial errors in the experimental techniques, conditions, evaluation criteria, statistical design, doses, and subjects used in the papers published in this period $[19,25,42,78]$. Some early studies made no use of placebo or did not standardise their doses or use non-reproducible means of strength assessment $[19,65,78]$. Reviewers have often confused and compared studies using congenitally or pathologically hypogonadal men with those in which normal or exercising subjects were used [42]. 
In 1975 one of the first scientifically controlled, cross-over studies demonstrated a small but significant increase in strength in subjects taking clinical doses of AS compared to controls [22]. It was established in 1980, that low doses of anabolic steroids produce a significant effect on muscle strength only in trained athletes who exercise regularly and intensively and who maintain a high protein intake [34, $80]$. Thus these aspects must all be controlled in an investigation of AS action. Exercise and training regimes cause increases in muscle mass and strength which are often difficult to differentiate from the effects of low doses of anabolic steroids [25]. Once early experimenters had established that therapeutic doses of anabolic steroids do increase muscle strength, it was then questioned as to whether the high doses used by many abusers were necessary.

There is an obvious ethical problem in submitting normal subjects to doses of AS in excess of $5000 \mathrm{mg}$ per week. However, a number of research groups have now established unequivocally that anabolic steroids in supra-physiological doses in maximally trained athletes do produce statistically significant increases in muscle strength and mass [7, 8]. Results from biopsy studies in weightlifters show that the number of muscle fibres and the average fibre size in muscles such as the trapezius were increased in anabolic steroid abusers compared to non-abusers [38]. The effect of AS on the human deltoid muscle, has been localised to an increase in size in the Type II muscle fibres [31] and this complements earlier studies showing that, at least in mammals, testosterone differentially increases the size of slow twitch rather than fast twitch muscles $[42,66]$. As a generalisation, testosterone and therefore, probably all anabolic steroids, increase upper body muscle power more than lower body power, and increase maximal voluntary strength and leg power but have little effect on muscle fatigability or muscle tension [70].

What determines the adult human response to T and AS ? In adult males there is considerable ethnic variation in serum concentrations of both $\mathrm{T}$ and Sex Hormone Binding Globulin (SHBG) [33]. SHBG is a major determinant of the bioavailibity of $\mathrm{T}$ in males and females [33]. Total Bound and calculated free $\mathrm{T}$ have been found to be lower in Pakistani men than in either Caucasians or Afro-Caribbeans [33]. These results need further evaluation in order to elucidate the possible influence of SHBG on anabolic / androgen responsiveness.

Since AS and T are known to produce most of their effects via interaction with a genomic Hormone Response Element (HRE), it might be expected that polymorphisms of this Androgen Receptor (AR) gene might correlate with differences in the general responsiveness to AS, since at least one research group has demonstrated a relationship between the increased length of the AR gene (in terms of increased numbers of repeats of the trinucleotide CAG) and reduced susceptibility to prostate cancer [33]. However, a recent study has shown only weak association between CAG-repeat polymorphisms of the AR gene and the response to $\mathrm{T}$ in terms of thigh muscle volume and lean body mass [79]. The major determinants of $T$ responsiveness in this study were age, dose of $\mathrm{T}$ and the serum concentration of prostate specific antigen [79]. However, AR numbers must have some influence over the response to AS in humans since AR receptor upregulation has been reported in muscle exposed to supraphysiological doses of AS [68]. This controversy may be resolved by the recent observation that different muscles such as the trapezius and vastas lateralis contain different concentrations of $A R$ and respond differently in terms of AR receptor upregulation in response to training and AS [39].

\section{ANABOLIC STEROID SIDE EFFECTS}

The side effects of anabolic steroids occurring as a result of clinical doses of the drugs are well documented and have been discussed in detail recently $[10,25,42,43,49]$. One of the commonest side effects is sodium retention which gives rise to water retention and then oedema [32, $62]$. Water retention and increased erythropoesis contribute to an increase in blood volume $[42,62]$ and also to the increased weight gain that occurs following anabolic steroid administration $[32,43]$. Much of the initial increase in muscle size and bulk that occurs following AS administration is due to the retention of water in the muscle tissue and not to an increase in protein content or muscle fibres [32, 63]. More serious side-effects, associated with the prolonged use of AS, include jaundice and hepatic carcinoma $[28,43]$. In males, additional side effects include suppression of LH and FSH secretion leading to atrophy of the testis [76], severe reductions in or cessation of testosterone secretion [17, 76] and azoospermia [36]. There is an increased risk of prostate hyperplasia and possibly prostatic carcinoma [43]. Side effects in females include the appearance of male secondary sexual characteristics and the suppression of menstruation [25, 42, 43]. Paediatric use of AS can cause growth stunting via epiphyseal closure and also precocious puberty in male children [10, 25, 43].

Many different types of study indicate that AS induce feelings of increased energy, well being, improved mood and increased aggressiveness $[10,28]$. Generally, studies and reviews of behavioural effects of AS concentrate heavily on the negative effects on behaviour, which may only be seen at the high doses administered in sporting abuse [43]. It should be emphasised that some of the negative effects observed after the administration of AS may be due to the effect of changes induced in the secretion of other hormones and not a direct action of AS themselves [17]. This is 
discussed in a later section along with the negative and addictive effects of AS. There is no evidence in the current scientific or clinical literature that AS addiction occurs when AS are administered at therapeutic doses [10].

\section{ANABOLIC STEROID SIDE EFFECTS IN SPORTING ABUSE}

Some of the side effects that occur as a result of abuse in sport are simply amplifications of those previously described. However, the supraphysiological doses commonly taken by cheating athletes cause additional side effects, some of which are reversible upon cessation of steroid abuse but may also cause chronic and irreversible side effects [42]. The long-term effects and other side effects of anabolic steroid abuse is an under researched but important topic [25].

\section{Hypothalamic pituitary and endocrine side effects}

Acute and chronic administration of AS suppresses the plasma levels of gonadotrophins [76], testosterone [17] and thyroid hormones T3 and T4, but has an insignificant effect on pituitary-adrenal hormones [17]. In a recent study, changes in aggressiveness during administration of methyl testosterone correlated specifically with increases in free plasma thyroxin [17]. These paradoxical findings with thyroid hormones add to the debate about the direct and indirect role of AS and behavioural changes. A more serious side effect of AS on the hypothalamico-pituitary axis has also been reported recently in a male body-builder in whom there was severe hypogonadism, and plasma FSH and LH levels were undetectable but the sperm count was normal [76]. These abnormalities were present 3 months after the cessation of AS abuse and the patient eventually became eugonadal only after treatment with 200 microgrammes of LHRH on 3 consecutive days [76]. Gynaecomastia sometimes occurs in athletes abusing moderate to high doses of AS [23] and the frequency of this side effect increases with chronic abuse [23]. The breast enlargement is caused by the aromatisation of certain AS such as T, but not nandrolone, to oestradiol [49]. It is for these reasons that AS abusers concomitantly administer tamoxifen, an oestradiol receptor antagonist, and also aminoglutethimide, an aromatase inhibitor [23].

Anabolic steroids have been shown to increase insulin resistance in one study [13], while in another, nandrolone but not testosterone, increased glucose uptake into muscle [35]. It is suggested that the ability of an AS to be aromatised to oestradiol may influence its effect on glucose homeostasis [35.]

\section{Cardiovascular side effects}

Cardiovascular side effects are possibly the most intensive- ly researched consequences of anabolic steroid abuse. Anabolic steroids have been shown to increase the blood volume but in 8 of the nine cases reviewed by Rockhold [62] the subjects were non-athletes. In athletes treated with methandionone, there was a $15 \%$ increase in total blood volume. Most of these studies, including the one containing athletes, failed to control for treatment; so the increase in blood volume could have been due to increased erythropoiesis and not to a direct increase in the blood volume [62].

There are many documented studies and reports showing that hypertension is linked to anabolic steroid abuse [28, $72,80]$, but others show minimal or contradictory effects or no effect on blood pressure [62]. It has also been suggested that hypertension may be induced by only certain types of AS [62]. Ventricular function in animals is impaired by administration of anabolic steroids [51] and the pathological changes that appear are similar to those found at autopsy in sportsmen who have been abusing AS [2]. In intensely training athletes, AS induce left ventricular thickening, an increase in the end-diastolic volume and relaxation index [80]. A study by Niemmen reported the above findings and also cardiac hypertrophy in 4 young weightlifters. 2 of its four weightlifters additionally had symptoms of heart failure and one developed a massive thrombosis in both ventricles [2].

The micro-vascular effects of anabolic steroid abuse have been investigated recently. Ebenbichler et al [18] examined arteriolar flow mediated dilatation (FMD) in 20 non-smoking body-builders. They found that FMD was reduced in body builders compared to non-abusing controls, but GTN (Glyceryl TriNitrate, an anti-angina drug) induced vasodilatation was reduced but not significantly. These findings correlated with a marked reduction in HDLC levels in some athletes. It could be concluded that anabolic steroid abuse is associated with an atherogenic blood lipid profile coupled with endothelial dysfunction, leading to an increased risk of atherosclerosis.

Anabolic steroids increase blood triglyceride and cholesterol levels [2], and lower blood levels of high-density lipoprotein (HDL) - principally the $\mathrm{HDL}_{2}$ and $\mathrm{HDL}_{3}$ fractions, while the concentration of low-density lipoprotein (LDL) is increased $[2,46]$. As a result of these changes in the blood lipoprotein profile, the ratio of free cholesterol to HDL-bound cholesterol rises [48]. Testosterone appears to have the least effect of all the AS on the blood lipoprotein profile [46]. The significance of these findings is that the U.S. Framingham study has shown that a mere reduction of 105 in the HDL concentration could increase the chances of a coronary heart disease by as much as $25 \%$. The HDL-lowering effect of AS has been determined as $25 \%$ in one study [15] and as high as $52 \%$ in another [62]. For 
comparison, in normal males, $25 \%$ of cholesterol is in the form of HDL while in AS abusers only $7.8 \%$ of cholesterol is HDL-bound [25]. The greatest reduction in bound cholesterol is observed with orally administered AS [46]. However, several studies show that the reduction in HDLbound cholesterol can be reversed when the AS abuse is stopped $[15,45,62]$. The time for levels to return to normal varies from 3-5 weeks $[45,62]$ to $6-12$ weeks [15]. A lowering of serum HDL is a risk factor for cardiovascular and cerebrovascular disease $[2,45,46]$, but at the same time total cholesterol levels may remain unchanged [27, 43]. This may lead the AS abuser, who is monitoring his cholesterol levels, to a false sense of security since the atherosclerosis associated with AS abuse may not be linked directly to cholesterol levels but to other changes in lipid and also triglyceride metabolism [27, 43]. In 1984, Goldman [28] reviewed a number of cases of fit healthy athletes aged $<40$ years who developed cardiovascular disease (CVD) while abusing anabolic steroids. Lukas [45] could find only 1 case of an athlete dying of CVD while abusing anabolic steroids in published research up to 1992. One reason for these low numbers of athletes dying in an apparently high-risk situation is that AS abusers who are athletes may be fitter than the rest of the population. This may delay pathological changes until late in life [71]. One analysis has documented a series of cases of severe CVD in AS abusers. Although there was only 1 death, there were several severe cases that were only saved from death by intensive treatment and possibly their young age [71]. Analysis of all these recent reviews and reports is complicated by the different drug regimes and doses used and by the life style of the participants, particularly in relation to smoking [25]. This aspect needs more research.

The above pathological changes in HDL and cardiac function might be expected to increase blood clotting and further increase the risk of CVD [46]. Studies in animals suggest that AS do increase the risk of clotting disorders and embolism. There is an association between anabolic steroid abuse and increased platelet aggregation [45]. In these studies there was one case of anabolic steroid induced stroke [46] and 3 cases of pulmonary embolism associated with anabolic steroid abuse and one case of venous thrombosis [71].

\section{Hepatic and Renal Effects}

Anabolic steroids even in clinical doses, induce increases in liver enzyme levels $[22,32]$ and at higher supra physiological levels, jaundice is a frequent side-effect [43], though these hepatic side-effects are usually reversible upon cessation of AS abuse [43]. The jaundice is of the intra-hepatic, cholestatic type : resulting from reduced flow and increased retention of bile in the bile capillaries of the hepatic lobules [69]. There has been one recent report of toxic hepatitis resulting from acute supraphysiological abuse of AS. In this case, hepato-cellular necrosis was confirmed by biopsy [69] and the abnormalities disappeared after 12 weeks of intensive care [69].

The association between AS administration and hepatic carcinoma was first established in 1965 [28]. The 17 alphaalkylated anabolic steroids are the drugs most frequently associated with this condition [28]. AS abuse is also associated with Wilms Tumour of the kidney [53].

\section{Effects on the Prostate}

For many years there has been a suspicion that AS abuse is linked to prostate carcinoma. A review of 3 large casecontrolled studies found a strong though not unequivocal link between increased AS levels and prostate cancer with $T$ having the stongest association with this carcinoma [54]. An earlier more general survey of AS side-effects and adverse effects found only one case of prostate cancer [71]. The risk of prostate cancer is enhanced in males by the presence of a polymorphism of the AR gene [50]. This polymorphism, involving a reduced number of repeats of the CAG trinucleotide is most common in African Americans [50]. Thus, by the use of genotyping, it may be possible to determine, in advance, those individuals most susceptible to this side effect.

\section{Effects on fertility}

Administration of AS inhibits the release of FSH and $\mathrm{LH}$ from the anterior pituitary in males and females [37, 47]. Doses of anabolic steroids as low as $15 \mathrm{mg}$ per day for 2 months can cause up to $75 \%$ reduction in sperm count as well as azoospermia [36]. The severity of the gonadotrophic suppression and the consequent anti-fertility effects depend on the dosage and duration of the AS abuse [47]. Normalisation of sperm counts after AS abuse may be enhanced by treatment with hCG $[26,74]$ or with $\mathrm{LH}-\mathrm{RH}$ [76]. However a return of the sperm count to normal does not necessarily mean that the sperms produced are fertile [43]. Evidence that AS can cause permanent infertility are equivocal and one study has found no evidence of chronic effects in young males [71].

\section{Effects on libido and behaviour}

Libido in males and females is influenced by testosterone but studies of the effects of T and AS on libido are complicated by the use of hypogonadal patients rather than eugonadal subjects. Several studies have indicated the importance of $T$ in maintaining key aspects of male sexuality such as erectile function, sexual fantasies $[4,5]$. However, in one study doses of $500 \mathrm{mg}$ per week for a 14 week period caused no increase in male libido [85].

There is conflicting evidence about the effects of AS on 
behaviour. While at least one reviewer found no relationship between AS administration and increased aggression [3] another later survey reported unreliable and equivocal effects of AS on behaviour [77]. Several investigations have reported increased feelings of energy, aggressiveness and elevated mood in athletes abusing anabolic steroids [6, 57, 64]. Using high doses in normal volunteers, 2 studies have shown that hostility, irritability, euphoria, drive and sexual arousal were increased by AS $[17,57]$ and another has shown that aggressive-responding behaviour was increased by AS [41]. However, when supra-physiological doses of anabolic steroids are used in normal men an increase in aggression is not always observed [43]. The underlying cause of these changes has recently been investigated in terms of observations on plasma / serum endocrine changes [17] and changes in cerebrospinal fluid (CSF) composition [16]. Interestingly some behavioural changes have been associated with reductions in thyroid hormone levels [17].

\section{Effects on mental state}

The effects of anabolic steroids on the mental state of patients and abusers have been shown to be as equivocal as the effects on behaviour. Women suffering from clinical post-natal depression have been shown to have low testosterone levels [1]. AS have been shown to have anti-depressant effects in several specific groups of depressed patients $[58,60,67]$ including HIV sufferers [60] and they have also been added to the treatment regime in some patients with treatment resistant depression $[58,67]$.

Conversely, several cases of mania have been reported in anabolic steroid abusers $[40,55]$ while depressed anabolic steroid abusers attempting to withdraw from anabolic steroids have become manic when treated with anti-depressant drugs $[40,77]$.

It is commonly assumed that aggressiveness and hostility are important components of the modern sports person's personality. However, this may only true of certain sports such as wrestling [61]. While some studies have demonstrated general increases in hostility and aggressiveness associated with AS abuse [57] others have found evidence of hostility, violence and physical abuse of partners by individuals abusing anabolic steroids [12]. However, when low doses of AS are used (110-550mg per week), no increase in hostility could be detected [85]. At least 8 welldocumented cases of suicide have been linked to withdrawal from AS abuse [73], while analysis of CSF testosterone levels in 46 Swedish suicide attempters found lower Testosterone levels than in aggressive / violent patients in other studies [30]. AS abuse also appears to increase the risk of experiencing physical violence, including murder [54].

\section{Addiction and dependence}

Several studies in the 1980's have demonstrated addiction and dependency in male AS abusers $[10,40]$ but only one case in a female [14]. A sex steroid hormone dependency disorder has been described [40] and the biochemical, physiological and psychological factors relating to AS dependency have been proposed [9] and summarised [10]. Recently, a muscle dysmorphic syndrome has been suggested as one possible cause of dependency [56] and this may have several forms of expression and may be linked to anorexia in males [52]. Fear of "muscle meltdown" resulting from the cessation of anabolic steroid abuse has been proposed as one possible psychological component of AS addiction [25]. As early as 1989, a link between AS abuse and serious crime was suggested [44]. The underlying personality of AS abusers [6] and dependents [9] has also recently been analysed and an association between AS abuse and social image conditioning has been suggested [82]. Personality factors such as narcissism and low empathy have been associated with AS abuse in at least one study [59]. Several reviewers have emphasised that the majority of athletes and body builders who abuse AS do not report major psychiatric symptoms $[6,45]$ or refrain from doing so [45]. It is also not necessarily true that an AS abuser who feels more aggressive and self-reports more aggression will behave violently or develop a mental disorder [6].

\section{Longevity}

Only in the past 5 years have there been any serious attempts to examine the influence of anabolic steroids on mortality. In a study of 62 elite power lifters in Finland, premature death was 4.6 times higher in AS abusers than in a control population who were not abusing AS [53]. A further examination of the subjects of this study showed that power-lifting itself does not increase mortality rates and so the increase in mortality in the earlier study was ascribed to the effect of AS $[53,54]$.

\section{CONCLUSION}

AS have been abused in athletes and sport for at least 50 years [86]. Despite many detailed studies demonstrating several acute and chronic physical and mental side effects of anabolic steroids, most of these side effects appear to be reversible [45]. We urgently need more studies on who is likely to be most susceptible to side effects and what the effects of these drugs are on mortality. Outside sport, we need to be able to cure the social, cosmetic abuse of the drugs. Whether the Anabolic Sorcerer will ever return to remove the anabolic spell remains to be seen. 


\section{REFERENCES}

1. ALDER E.M., COOK A., DAVIDSON D., WEST C. BANCROFT J. : Hormones, mood and sexuality in lactating women. Br. J. Psychiatry, 1986, $148:$ 74-79.

2. ALEN M., RAHKILA P. : Anabolic-androgenic steroid effects on endocrinology and lipid metabolism in athletes. Sports Med., 1988, $6: 327-332$.

3. ARCHER J. : The influence of testosterone on human aggression. Br. J. Psychol., 1991, 82 : 1-28.

4. BAGATELL C.J., BREMNER W.J. : Androgens in men uses and abuses New Engl J. Med., 1996, 334 : 707-714.

5. BAGATELL C.J., HEIMANN J.R., RIVIER J.E. : Effects of endogenous testostrone and estradiol on sexual behaviour in normal young men. J. Clin. Endocrinol. Metab., 1994, 78 : 713-716.

6. BAHRKE M.S. : Psychological effects of endogenous testosterone and anabolic-androgenic steroids. In : Yesalis C. ed. Anabolic Steroids in sport and exercise. Champaign Il, Human Kinetics Publishers, 2000 : 94-106.

7. BHASIN S., STORER T.W., BERMAN N. et al. : The effects of supraphysiologic doses of testosterone on muscle size and strength in normal men. N. Engl. J. Med., 1996, 335 : 1-7.

8. BHASIN S., WOODHOUSE L., STORER T.W. : Proof of the effect of testosterone on skeletal muscle. J. Endocrinol., 2001, $170: 27-38$.

9. BROWER K.J. : Anabolic steroids : potential for physical and psychological dependence. In : Yesalis C. ed. Anabolic steroids in sport and exercise. Champaign Il, Human Kinetics Publishers, $2000: 279-304$.

10. BROWER K.J. : Anabolic steroid abuse and dependence. Curr. Psychiatry Reports, 2002, 4 : 377-387.

11. BROWER K.J., BLOW F.C., YOUNG J.P., HILL E.H. : Symptoms and correlates of anabolic steroid dependence. Br. J. Addict., 1991, $86: 759-768$.

12. CHOI P.Y.L, POPE H.G. : Violence towards women and illicit androgen-anabolic steroid use. Ann. Clin. Psychiatry, 1994, 6 : 21-25.

13. COHEN J.C., HICKMAN R. : Insulin resistance and diminished glucose tolerance in powerlifters ingesting anabolic steroids. $\mathrm{J}$. Clin. Endocrinol. Metab., 1987, 64 : 960-963.

14. COPELAND J., PETERS R., DILLON P. : Anabolic-androgenic steroid dependence in a woman. Austr. N.Z. J. Psychiatry, 1998, $32: 589-591$.

15. COSTILL D.L., PEARSON D.R., FINK W.J. : Anabolic steroid use among athletes. Changes in HDC-C levels. Phys. Sports Med., 1984, $12: 113-117$.

16. DALY R.C., SU T-P., SCHMIDT P.J., PICKAR D., MURPHY D.L., RUBINOW D.R. : Cerebrospinal fluid and behavioural changes after methyltestosterone administration. Arch. Gen. Psychiatry, 2001, $58: 172-177$.

17. DALY R.C., SU T-P., SCHMIDT P.J., PAGLIARO M., PICKAR D., RUBINOW D.R. : Neuroendocrine and behavioural effects of high-dose anabolic steroid administration in male normal volunteers. Psychoneuroendocrinology, 2003, 28 : 317-331.
18. EBENBICHLER C.F., STURM W., GANZER H. et al. : Flowmediated, endothelium dependent vasodilation is impaired in male body builders taking anabolic-androgenic steroids. Atherosclerosis, 2001, $158:$ 483-490.

19. ELASHOFF J.D., JACKNOW A.D., SHAIN S.G., BRAUNSTEIN G.D. : Effects of anabolic-androgenic steroids on muscular strength. Ann. Int. Med., 1991, $115:$ 387-393.

20. EVANS N.A. : Gym and tonic : a profile of 100 male steroid users. Br. J. Sports Med., 1997, 31 : 54-58.

21. FORBES G.B. : The effect of anabolic steroids on lean body mass. The dose response curve. Metabolism, 1985, 34 : 571-573.

22. FREED D.L.J., BANKS A.J., LONGSON D., BURLEY D.M. : Anabolic steroids in athletes: cross-over double blind trial in weightlifters. Br. Med. J., 1975, 2 : 471-473.

23. FRIEDL K.E., YESALIS C.E. : Self-treatment of gynaecomastia in body builders who use anabolic steroids. Phys. Sports Med., 1989, $17: 67-79$.

24. GEORGE A.J. : Drugs in Sport - chemists $v$ cheats -a score draw ! Chem. Rev., 4 : 10-14.

25. GEORGE A.J. : Anabolic steroids. In : Mottram D.R. ed. Drugs in Sport $3^{\text {rd }}$ Edition. London, E. \& F. Spon, 2003, 138-188.

26. GILL G.V. : Anabolic steroid induced hypogonadism treated with human chorionic gonadotrophins. Postgrad. Med. J., 1998, $74: 45-46$.

27. GLAZER G. : Arthrogenic effects of anabolic steroids on serum lipid levels. Arch. Int. Med., 1991, 151 : 1925-1933.

28. GOLDMAN B. : Death in the locker room : Steroids and sports. London, Century Publishing, 1984.

29. GUO Z., BENTEN W.P., KRUCKEN J., WUNDERLICH F. : Nongenomic testosterone calcium signalling : genomic actions in androgen receptor- free macrophages. J. Biol. Chem., 2002, 277 : 29600-29607.

30. GUSTAVSSON G., TRASKMAN-BENDZ L., DEE HIGLEY J., WESTRIN $\AA$. : CSF testosterone in 43 male suicide attempters. Europ. Neuropsychopharmacology, 2003, 13 : 105-109.

31. HARTGENS D., VAN STRAATEN H., FIDELDIJ S., RIETJENS G., KEIZER H.A., KUIPERS H. : Misuse of androgenicanabolic steroids and human deltoid muscle fibers : differences between polydrug regimens and single drug administration. Europ. J. Appl. Physiol., 2002, 86 : 233-239.

32. HAUPT H.A., ROVERE G.D. : Anabolic steroids : A review of the literature. Am. J. Sports Med., 1984, $12: 469-484$.

33. HEALD A.H., IVISON F., ANDERSON S.G., CRUICKSHANK K., LAING I., GIBSON J.M. : Significant ethnic variation in total and free testosterone concentration. Clin. Endocrinol., 2003, $58: 262-266$.

34. HERVEY G.R., KNIBBS A.V., BURKINSHAW L. et al. : Effects of methandione on the performance and body composition of man undergoing athletic training. Clin. Sci., 1981, 60 : 457-461.

35. HOBBS C.J., JONES R.E., PLYMATE S.R. : Nandrolone, a 19 nortestosterone, enhances insulin dependent glucose uptake in normal men. J. Endocrinol. Metab., 1996, 81 : 1582-1585. 
36. HOLMA P.K. : Effects of an anabolic steroid (methandienone) on spermatogenesis. Contraception, 1979, 15:151-162.

37. JAROW J.P., LIPSCHULTZ L.I. : Anabolic steroid induced hypogonadotrophic hypogonadism. Am. J. Sports Med., 1990, 18: 429-431.

38. KADI F., ERIKSSON A., HOLMNER S., BUTLER-BROWNE G., THORNHILL L.E. : Cellullar adaptation of the trapezius muscle in strength trained athletes. Histochem. Cell Biol., 1999, $111: 189-195$.

39. KADI F., BONNERUND P., ERIKSSON A., THORNELL L.E. : The expression of androgen receptors in human neck and limb muscles : effects of training and self-administration of androgenic-anabolic steroids. Histochem. Cell Biol., 2000, 113 : 25-29.

40. KASHKLIN K.B., KLEBER H.D. : Hooked on hormones ? An anabolic steroid addiction hypothesis. J. Amer. Med. Assoc., $1989,262: 3166-3170$.

41. KOURI E.M., LUKAS S.E.. POPE H.G., OLIVA P.S. : Increased aggressive responding in male volunteers following the administration of gradually increasing doses of testosterone cypionate. Drug Alcohol Depend.. 1995, $40: 73-79$.

42. KUHN C.M. : Anabolic Steroids. Endocrinol. Rev., 2002, 13 : 411-434.

43. KUTSCHER E.C., LUND B.C., PERRY P.J. : Anabolic Steroids - A review for the clinician. Sports Med., 2002, 32 : 285-296.

44. LUBELL A. : Does steroid abuse cause - or excuse - violence ? Phys. Sport Med., 1989, 17 : 176-185.

45. LUKAS S.E. : Current perspectives on anabolic-androgenic steroid abuse. Trends Pharmacol. Sci., 1993, $14: 61-68$.

46. LOMBARDO J.A., HICKSON P.C., LAMB D.R. : Anabolic/androgenic steroids and growth hormone. In : Lamb D.R., Williams M.H. eds. Perspectives in Exercise Science and Sports Medicine, Vol. 4 : Ergogenics - Enhancement of Performance in Exercise and Sport. New York, Brown and Benchmark, 1991, 249-278.

47. MCINDOE J.H., PERRY P.J., YATES W.R. et al : Testosterone suppression of the HPT axis. J. Invest. Med., 1997, $45: 441-447$.

48. MILLAR A.P. : Licit steroid use - hope for the future. Br. J. Sports Med., 1994, 28 : 79-83.

49. MOTTRAM D.R., GEORGE A.J. : Anabolic steroids. Clin. Endocrinol. Metab., 2000, 14 : 55-69.

50. NELSON K.A., WHITE J.S. : Androgen receptor CAG repeats and prostate cancer. Am. J. Epidemiol., 2002, $155: 883-890$.

51. NIEMINEN M.S., RAMO M.P., VIITASALO M. et al. : Serious cardiovascular side effects of large doses of anabolic steroids in weight lifters. Europ. Heart J., 1996, 17 : 1576-1583.

52. OLIVARDIA R., POPE H.G., HUDSON J.L. : Muscle dysmorphia in male weightlifters : a case control study. Am. J. Psychiatry, 2000, $157: 1291-1296$.

53. PARSINNEN M., KINJALA U., VARTIAINEN E., SARNA S., SEPPALA T. : Increased premature mortality of competitive powerlifters suspected to have used anabolic agents. Int. J. Sports Med., 2000, 21 : 225-227.

54. PARSSINEN M., SEPPALA T. : Steroid use and long-term health risks in former athletes. Sports Med., 2002, $32: 83-94$.

55. POPE H.G.. KATZ D.L : Psychiatric and medical effects of anabolic-androgenic steroid use. Arch. Gen. Psychiat., 1994, 51 : 375-382.

56. POPE H.G., GRUBER A.J., CHOI P., OLIVARDIA R., PHILLIPS K.A. : Muscle dysmorphia. Psychosomatics, 1997, 38 : 548-557.

57. POPE H.G., KOURI E.M., HUDSON J.I. : Effects of supraphysiological doses of testosterone on mood and aggressionin normal men. Arch. Gen. Psychiatry, 2000, 57 : 133-140.

58. POPE H.G., COHANE G.H., KANAYAMA G., SIEGEL A.J., HUDSON J.I. : Testosterone gel supplementation for men with refractory depression : a randomised placebo-controlled trial. Am. J. Psychiatry (in press)

59. PORCERELLI J.H., SANDLER B.A. : Narcissism and empathy in steroid users Ann. J. Psychiatry, 1995, $152: 1672-1674$.

60. RABKIN J.G., WAGNER G.J., RABKIN R. : A double blind, placebo controlled trial of testosterone therapy for HIV-positive men with hypogonadal symptoms. Arch. Gen. Psychiatry, 2000, $57: 141-147$.

61. RAGLIN J.S. : Psychological factors in sport performance. Sports Med., 2001, 31 : 875-890.

62. ROCKHOLD R.W. : Cardiovascular toxicity of anabolic steroids. Ann. Rev. Pharmac. Tox., 1993, 33 : 497-520.

63. ROGOL A.D., YESALIS C.E. : Anabolic-androgenic steroids and athletes: What are the issues ? J. Endocrinol. Metab., 1992. $74: 465-469$.

64. RUBINOW D.R., SCHMIDT P.J. : Androgens, brain and behaviour. Am. J. Psychiatry, 1996, 153 : 974-984.

65. RYAN A.J. : Anabolic steroids are fool's gold. Fed. Proc., 1981, $40: 2682-2688$

66. SACHS B.D., LEIPHEIMER R.E. : Rapid effect of testosterone on striated muscle activity in rats. Neuroendocrinology, 1988, 48: 453-458.

67. SEIDMANN S.N., RABKIN J.G. : Testosterone replacement therapy for hypogonadal men with SSRI-refractory depression. J. Affect. Disord., 1998, 48: 157-161.

68. SHEFFIELD-MOORE M., URBAN R.J., WOLF S.E. et al. : Short-term oxandrolone administration stimulates net muscle protein synthesis in young men. J. Clin. Endocrinol. Metab., $1999,84: 27052711$.

69. STIMAC D., MILLI S., DINTINJANA R.D., KOVAC D., RISTI S. : Androgenic/Anabolic steroid induced toxic hepatitis J. Clin. Gastroenterol., 2002, 35 : 350-352.

70. STORER T.W., MAGLIANO L., WOODHOUSE L. et al. : Testosterone dose-dependently increases maximal voluntary strength and leg-power, but does not affect fatigability or specific tension. J. Endocrinol. Metab., 2003, 88 : 1478-1485.

71. STREET C., ANTONIO J., CUDLIPP D. : Androgen use by athletes : A re-evaluation of the health risks. Canad. J. Appl. Physiol., 1996, $21:$ 421-440.

72. SULLIVAN M.L., MARTINEZ C.M., GENNIS C. et al. : The cardiac toxicity of anabolic steroids. Prog. Cardiovasc. Dis., $1998,41: 1-15$. 
73. THIBLIN I., LINDQUIST O., RAJS J. : Cause and manner of death among abusers of anabolic androgenic steroids. J. Forensic Sci., 2000, $45: 16-23$.

74. TUREK P.J., WILLIAMS R.H., GILLBRAUCH J.H. et al : The reversibility of anabolic steroid induced azoospermia. J. Urol., 1995, $153: 1628-1630$.

75. UEKI M., OKANA M. : Doping with naturally occurring steroids. J. Toxicol. Toxin. Rev., 1999, 18 : 177-195.

76. VAN BREDA E., KEIZER H.A., KUIPERS H., WOLFFENBUTTEL B.H.R. : Androgenic anabolic steroid use and severe hypothalamic-pituitary dysfunction: a case study. Int. J. Sports Med., 2003, 24 : 195-196.

77. WILLIAMSON P.J., YOUNG A.H. : Psychiatric effects of androgenic and anabolic-androgenic steroid abuse in men : a brief review of the literature. J. Psychopharmac., 1992, $6: 20-26$.

78. WILSON J.D. : Androgen abuse by athletes. Endocrinol. Rev., 1988, $9: 181-199$.

79. WOODHOUSE L.J., REISZ-PORSZASZ S., JAVANBAKHT M. et al : Development of models to predict anabolic response to testosterone administration in healthy young men. Am. J. Physiol., 2003, 284 : 1009-1017.

80. WRIGHT J.E. : Anabolic steroids and athletics. Exerc. Sport Sci. Rev., 1980, $8:$ 149-202.

81. WRIGHT F., BRICOUT V., DOUKANI A., BONGINI M. : Nandrolone et nor-stéroïdes : substances endogènes ou xénobiotiques ? Sci. Sports, 2000, $15: 111-124$.

82. WROBLEWSKA A.M. : Androgenic-anabolic steroids and body dysmorphia in young men. J. Psychosom. Res., 1997, 42 : 225234.

83. WU F.C.W. : Endocrine agents of anabolic steroids. Clin. Chem., $1997,43: 1289-1292$.

84. YANG P., JONES B.L., HENDERSON L.P. : Mechanisms of anabolic androgenic steroid modulation of

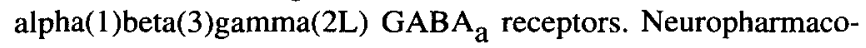
logy, 2002, $43: 619-633$.

85. YATES W.R., PERRY P.J., MACINDOE J., HOLMAN T. ELLINGRAD V. : Psychosexual effects of 3 doses of testosterone cycling in normal men. Biol. Psychiatry, 1999, $45: 254-260$.

86. YESALIS C., COURSON S., WRIGHT J. : History of anabolic steroid use in sport and exercise. In : Yesalis C. ed. Anabolic Steroids in sport and exercise. Champaign Il, Human Kinetics Publishers, 2000 : 54-56.

Communication au $\mathrm{XIX} \mathrm{X}^{\circ}$ Congrès de la Société d'Andrologie de Langue Française, Genève, 12-14 decembre 2002.

Manuscrit reçu : juillet 2003 ; accepté septembre 2003. 